\title{
Re-Imagining Research Partnerships: Thinking through "Co-Research" and Ethical Practice with Children and Youth
}

DIANE R. COLLIER

Brock University, Canada

\begin{abstract}
Intentions to co-research and engage in participatory research pervade education and social science research with children and particularly research on engagement in digital spaces, with digital tools. Starting in the 1900s, there were many attempts to explicitly describe co-research methods and intentions in education but recently co-research has been used in a more taken-for granted way. Using snapshots from three research projects, I trouble my own attempts at co-research. Firstly, in a two-year ethnographic study, research positions were shifted by following the children's lead and multimodal textmaking interests. Secondly, in an artsinformed classroom study of family photography and family stories, the ways in which the children understood the research process, and gave or withheld assent, influenced how they engaged as co-researchers. Finally, a larger comparative arts-informed study of youths' digital practices in Hamilton is explored with an eye to how coresearch evolved for the youth throughout the project. None of these projects were designed to engage with co-research in a comprehensive way. Yet, across these snapshots, a more nuanced understanding of co-research is envisioned; one that involves reflexive ethical practice and an emergent and attentive focus on consent.
\end{abstract}

KEYWORDS co-research; research ethics; children; participatory methods; family photos; multimodality; arts-informed research; collaborative research; youth; literacies

\section{Introduction}

Co-research is used frequently in qualitative research in education as part of a trend toward working more collaboratively in general - with children and youth, with educators, and with community members. As educational research becomes more common across community settings, the term $\mathrm{co}$ research is used to build connections across sectors, and to also build claims for more authentic and meaningful research, and research that can be 
disseminated in a way that crosses over the perceived boundaries between academic and non-academic worlds (Christenson \& James, 2017; Murray, 2017; Price \& Kerr, 2017). Discussions of co-research were initially connected to concerns about children's rights in education (as students, rather than research participants per se). More recently, claims of co-research that permeate educational research have been critiqued; co-research may be used to enhance researcher claims for authenticity and, potentially, as a way for them to relinquish responsibility to research participants for what happens throughout the research process (Holland, Renold, Ross, \& Hillman, 2010; Loutzenheiser, 2007). Ethical engagement with participants, whether children or not, is a matter of social justice. Participants should have a say in how research unfolds and how they are represented. At the same time, it may not be equitable to place responsibility for research on one's participants. It is this tension that the paper explores.

The research and the analysis presented here use a critical ethnographic perspective (Madison, 2011) that is informed by post-structural theorizing about the partiality of all analyses and perspectives (Davies, 2014; Pillow, 2003; St. Pierre, 2011). In my research, I have tried to work with an openness to how others - often children - might understand research processes and how they might direct what is happening as well as provide interpretations. This openness to others has involved considering what distinguishes child participants from other participants, ${ }^{1}$ on the one hand, but also, how one respects all research participants while at the same time recognizing their often limited investments or interest in research and its significance or value. This investment or interest connects to the overall design or process of coresearch that is used. In this paper, I think through whether co-research always or ever means more ethical research. It begs the question if fully ethical research is even possible. Is it desirable, and what can researchers live with? This inquiry relates to larger questions that are only partially addressed in the research here: What is co-research? Why would/should/could someone engage in co-research? and, What are the possibilities for and limitations of thinking of children as co-researchers?

The first section is an overview of the literature on children's voice and participatory research. Then, three aspects of co-research are described in relation to three of my research projects. These aspects include: following participants leads and interests, ongoing negotiation of consent/assent, and potential for decentring the researcher and making more space for others in research settings. The paper ends with potentials for thinking about coresearch, and some thoughts about framing and working with participants, especially those - here, children - who cannot legally consent to research participation. Examples presented here have implications for how research and participant roles might be shifted in research that wishes to be more

${ }^{1}$ In this paper, I use the term "children" as a collective term for those who are under 18, but sometimes use the term "youth" when talking specifically about high school students and older children up to 18 years old. 
ethical. At the same time, using the term co-research to describe research that simply values children's perspectives or input may not be helpful or ethical.

\section{Childhood, Children's and Youths' Voices, and Participation}

Co-research with children is informed by at least three other interconnected areas of study: historical, constructed notions of childhood and adolescence; the "children's voice" movement in the UK in the 1990's and subsequent adoption of this concept in research with children; and participatory research methods.

Morrow and Richards (1996) outline four prevailing notions of children and childhood used in research where children are participants: children as vulnerable (in need of protection), children as incompetent (unable to understand), children as powerless (adult-child relations important here), and children as social actors (able but with differences, and not a uniform group). In classrooms, homes, and research contexts, children are often viewed as dependent and powerless and requiring support in order to help them to act agentically and to share their voices. The desires of researchers and educators who want to give voice to children and to help them develop feelings of agency and empowerment, often belie a singular notion of what constitutes a child (e.g., Cruddas, 2007; Harwood, 2010; James, 2007). A child can be many things and have many degrees of understanding in research as well as varying perspectives. Beyond the fact that children cannot legally consent to research, there are children's voices who may not be that different from the voices of those who are not children.

Children's voices and viewpoints are often seen as collective and uniform even though experience might tell us differently. The binary of helplessagentic child is problematic but perhaps inevitable from a Western perspective that focuses on individualism, while at the same time, within families, communities, and schools, children's behavior and everyday lives are more constrained and streamlined than ever (Bragg, 2007; Buckingham, Bragg, \& Kehily, 2015; Livingstone \& Sefton-Green, 2016). Leisure time, especially for middle-class children, is more prescribed and their progress is monitored more closely than ever. Children are dependent on parents who give consent for their research participation but, at the same time, educators and researchers often want to see them as "knowing subjects" (Balen et al., 2006, p. 43).

Educational research focused on children's or young people's voices is not new, and during the late $20^{\text {th }}$ and early $21^{\text {st }}$ century, children's voice research in the United Kingdom permeated research and governmental sponsored education research. The Children's Act in the United Kingdom in 1989 legislated the right of children to participate in their own education and this led to widespread programs of consultation with children in schools about their experiences in schools in order to inform school decisions (Fielding, 
2004; Frost, 2007). The children's voice movement set out to reframe children as agentic, with a say in how their educational lives are run and should be run (Ravet, 2007). Interest in children's voices and participant voices has been taken up and critiqued by researchers in the social sciences, and in education particularly, who have questioned the notion of authenticity of voices, as voices are always situated, fluid, and influenced by power relations (Bragg, 2010; Clark, Flewitt, Hammersley, \& Robb, 2014; Jackson $\&$ Mazzei, 2009). The children's voice movement resonates with educational thinking in other English-speaking countries, as teachers and administrators in schools have attempted to involve students in their own education within schools (e.g., Bragg, 2007; Harland, 2007). Much of the research involving "children's voices" or "pupil voice" has been explicitly framed as action research in school settings with teachers as researchers or researchers who are invited to schools as part of a participatory research project and to encourage children's development as democratic citizens (Jans, 2004; Thomson, Berriman, \& Bragg, 2018).

Participatory research perspectives are often framed as better and more authentic than non-participatory research even though the nature and extent of what is described as co-research or participatory research is often not clearly elucidated. Examples of those who describe how co-research happens include research and pedagogies that have engaged children in decisionmaking in schools ranging from everyday decisions such as how to organize toilet visits, to more substantial and potentially powerful acts, such as giving input about hiring a new teacher (Clark et al., 2014). Researchers who support participatory approaches with children speak of "consulting pupils directly" and "centralizing their voices" (Leitch et al., 2007, p. 462), although this is carried out in different ways and to different degrees.

Child participants can play a role in the choice of informants, the posing of questions, and collection and analysis of data (Bird, Colliver, \& Edwards, 2014). Some innovative approaches have included encouraging pre-school children to choose their own pseudonyms (i.e. "Barbie" and "Bob the Builder" in MacNaughton, Smith, \& Davis, 2007); using pedagogical techniques familiar to students (Semenec, 2018; Snelgrove, 2005); having children collect data by videotaping and interviewing other students and adults (Medina \& del Rocio Costa, 2010); using alternative non-school settings to meet with students (Holland et al., 2010); and using multiple methods and innovative ways to talk to children in research contexts (Theobald, 2012).

Many researchers have attempted to be more explicit about their research processes, continually interrogating their own positions as researchers as they use multiple approaches to obtaining consent/assent while also considering non-participation as a source of data and an important part of the consent/assent process (Cook-Sather, 2007; Fielding, 2004; Punch, 2002). Others set a goal of engaging students as co-researchers, working with the research to shape and present stories that are collected, and some assume a 
least-adult role after Mandell's (1988) description of a more child-like researcher who waits to be invited into children's spaces and activities (Christensen, 2004). Researchers have argued for "authentic social research on children's fundamental right to be heard in the research context...[and]... the individual contribution and unique perspective that children of various ages can bring to the deliberations" (Grover, 2004, pp. 90-91). Much of this careful exploration of voice occurred in the 1990s and early 2000s, as many of the citations here reflect. Since that time, co-research has been often claimed as a given, and the probing of participation, and the questioning of claims for giving voice or empowering children are not always acknowledged (e.g., Cutter-Mackenzie \& Rousell, 2019; Murray, 2017; Warham, 2012).

Claims of authenticity have been challenged and complicated by some who engage in media production with youth (Bragg, 2010; Tilleczek \& Loebach, 2015). Beyond changes in methods and adoption of everyday practices and tools (such as the photo and video-taking practices with phones), Dayha (2017) calls for considerations of place, tools, and artifacts in understanding how youth share their voices. For the young Muslim girls in her study, different tools (laptop camera instead of handheld) and space (a university site rather than a classroom) allowed for stories to be made and told that did not seem possible in their usual contexts. In the end, it is impossible to avoid the fact that research is almost always bracketed by the researcher who initiates the study and then edits and translates the stories, always partial, collected for public presentation (Loutzenheiser, 2007). The power differential implicit in this bracketing is unavoidable. Holland et al. (2010) argue that participatory approaches do not always equalize power relations or even always result in "better" data, and that attentiveness to the how of children's participation in research can be more illuminating than a focus on how much. Attentiveness to power relations between academic researchers and children, and amongst children, is required.

When thinking about the implications of participatory research, one has to consider children's options for non-participation. In educational settings, the options for children's refusal of participation in a research project are limited (Bragg, 2010). Children may want to please the researcher, may want to go along with the decisions of peers, or may be pressured by teachers and administration to participate. In addition, the accommodations needed for non-participants in some projects, such as videotaped research projects, may isolate those students and make their school life less than comfortable. Students who participate may take up the values and perspectives (and voices) of adult researchers, becoming more complicit and helping to enforce existing power conditions through the research process. Children's experiences and perspectives in classrooms are always mediated and constructed though shared social meanings in educational settings (Graue \& Walsh, 1998). Research involving children's voices is always work about adult and child identities and intergenerational relationships (Cruddas, 2007). 


\section{Co-Researching}

There are three threads in the rest of this paper using examples from three different studies. Co-research is viewed through the ways in which researchers (a) follow participants' leads and interests, (b) engage in ongoing negotiations of consent and assent, and (c) attempt to decentre themselves and thereby make space for multiple and potentially contradictory perspectives.

\section{Co-Research as Following Leads and Interests}

The first study involved two children's multimodal textmaking practices across home and school. Trajectories of textmaking in various modes (i.e., video, audio, oral/singing, drawing) were traced across time and space. Over a two-year period, I looked at how children's multimodal literate expressions could be viewed across home and school and how their resources and social identities might influence their experiences at school. Processes rather than products of textmaking constituted this research that spanned home and school contexts and used participant observation and informal interview-style sessions. Although not conceptualized as a co-research study, following the examples of Hicks (2002) and Dyson (2003), the research was designed to follow the practices and interests of the children, rather than a pre-determined focus on reading or writing or friendship or families.

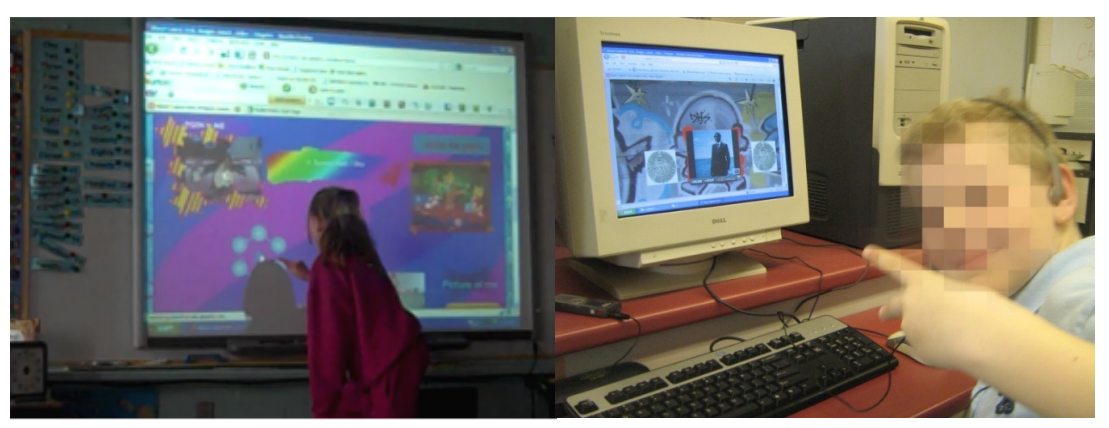

Figure 1. Stephanie and Kyle make digital posters, All About Me.

In Figure 1 above, Stephanie and Kyle were both working on digital posters at school, towards the end of the research period, and using research data to tell a story about themselves. Kyle's photo is blurred because my university-approved ethics forms, devised by me and my committee, required that I keep identities hidden. I use this image, though, because of the way I feel it expresses the spirit of many of my sessions with Kyle. Neither Stephanie or Kyle ever expressed discomfort with the sharing of images. At 
the beginning it was exciting to them, and I showed them published books and articles of the type I would be writing. Later on, at the end of two years, they found it less interesting or more commonplace.

They embraced the digital tools used to gather and generate ethnographic data and, over time, directed me to gather and record particular text-making moments. On the left-hand side of Figure 2 below, are photos that Stephanie directed me to take, or that she took herself of the activities and materials that she thought were worth sharing in her bedroom. She frequently decorated and redecorated her walls, coloured in colouring books and drew pictures in her room. Walls and shelves were covered with headbands, clothing, and collectible Barbie dolls. In Kyle's highly organized bedroom (below-right), book series were neatly stacked in the clothes cupboard above clothes, a television served as a vehicle for his PlayStation2, wrestling posters filled the walls, alongside handmade items commemorating his birth and early childhood. Kyle and his mother often sang along to YouTube videos in the evening and I did the same.
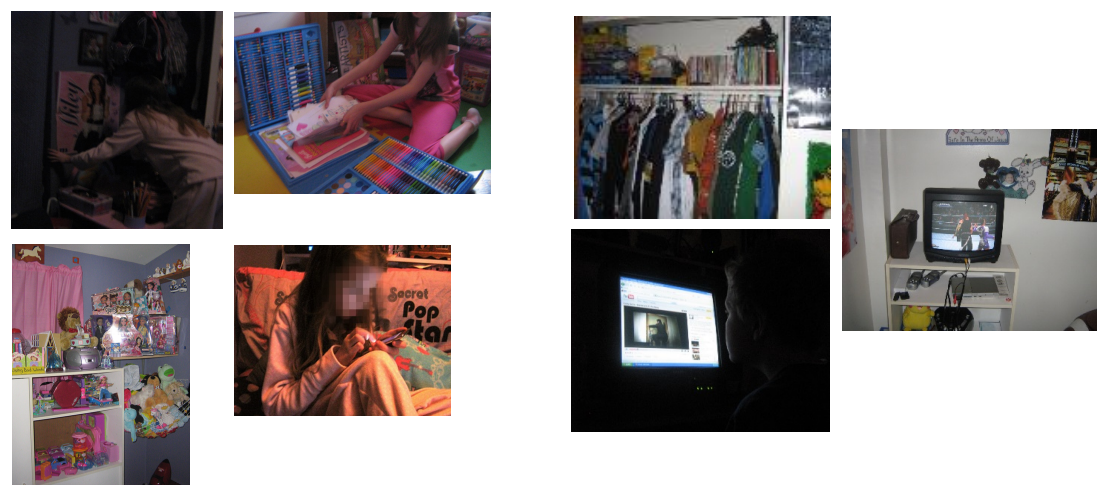

Figure 2. Stephanie's photos of making and sharing her room (left); Kyle's photos of collections and pastimes (right).

The photos in Figure 2 are at home, where Stephanie and Kyle were leading me, and deciding what to share, and in this context their positions as subjects of interest were palpable and explicit. They were leading, and I was the guest and learner.

I also spent a great deal of time with Stephanie and Kyle at school, in their class. Initially, they were acutely aware of my interest in them, more so on some occasions than on others. At times, this awareness translated to discomfort on the part of several other students in their class, and also, to an element of competition between them. Notions of "worthiness" as research participants were vocalized by both of them, and even generated conflict between them (which pre-existed the time and space of this study). Kyle stated that Stephanie had pulled the wool over my eyes. Perhaps he was not comfortable sharing the limelight with her, as he had been the first and 
longstanding participant in my original pilot study at his school. Regardless of my attempts to include all of the class in the research and respond to their sharing, Stephanie decided to frequently highlight her status as research participant to several girls, and on one occasion this upset one of the girls. I followed up with conversations with Stephanie and this girl.

Part of the reason that Stephanie was chosen for this project was my concern that girls like her - low-achieving by academic standards - were often invisible in research, and at the same time her visibility sometimes became problematic, as was mentioned earlier. In some ways Stephanie was a difficult subject and she really wanted, first and foremost, my attention, but also to engage in fun activities like drawing or using fashion and toy apps, and to tell me funny stories about her siblings and pets. She wished to do these things rather than talk about the research or her impressions of being part of a study. When I have presented or written about Stephanie and Kyle, audience members and readers are much more interested in the playful, humourous, and adult-focused ways that Kyle expressed himself and less so in Stephanie. This dilemma has led me to think more carefully about why we (or I) choose the participants we do and how there are less positive and more difficult stories that are avoided. Within Stephanie's class, I often found myself acting as a mediator to help her to enter social groupings and to advocate for her strengths with her teacher. I often found myself sharing Stephanie's accomplishments and interests (which were many) outside of school as a way of rounding out impressions of her as socially difficult and a challenged student.

Kyle and Stephanie had quite different voices, not one child voice, and there are interesting repercussions for following children's interests and the relinquishing of control that comes with this disruption. The process of following children's interests can diminish the control of researchers, which is one of the intentions of participatory research, and it can also lead in unexpected directions, especially as the presence of the researcher becomes less noticed over time. With both Stephanie and Kyle, my presence became less visible or at least more usual, and in our sessions, I would often have to remind them about the research. They sometimes seemed to forget that I was documenting what was happening. At the same time, like the other children in their class, they would fill me in if I was away, and sometimes they had taken notes to share with me. All of the children knew and acknowledged that I was there to learn from them. While following these particular children and listening to what they said and did, I felt that I was able to tell some things about some parts of their lives, but always through the lens of my perspective.

As mentioned in the discussion of Figure 1, at the end of the research, I asked Stephanie and Kyle to review all of the images, videos, and photocopies collected during the research, and they did. As a result, they created digital posters (along with the rest of the class) to tell a version of their lives. These posters, which are discussed elsewhere (Collier, 2014, 
2017), told very particular stories about them. Kyle's was about image - an image of him as a rapper, and a cool guy who loves money. Stephanie's was about her favourite things: dance, a puppy, her awards, paintings - some actually in her life and some to which she aspired. These stories are different from but overlap with my stories about them. These particular child participants shared their voices on a daily basis because of the relationships we built together, and shared their voices in ways that they sometimes controlled. These multiple perspectives are necessary to disrupt singular notions of children and their voices.

In online spaces, following children's interests and voices assumes that children have something to say. In this example, children did not appear to imagine audiences beyond me, despite my discussion of these future forums. During our sessions, I often told them the kinds of things I was learning and that I might write about. At the same time, ultimately I was the primary audience for the children's research participation. Children did some online work, but the audiences were small. I could have done more to share the findings of research with them, but I also do not believe that is always necessary. What is more important is to temper the claims that one makes, and remind the reader of the context, what happened, and the other stories and voices that are possible. I am left thinking about the complications of following children and their interests, whose voices are heard and whose are not, and the role of researchers in helping to share a variety of narratives.

\section{Co-Researching as Ongoing Negotiation of Consent/Assent}

Co-research can be seen in terms of the ongoing negotiation of consent and assent. In a recent project, Visualizing Families, children in the middle years of elementary school used arts inquiry to tell stories about their families through photos. They brought in family photos and over two months they used black and white printouts, iPads, and art materials to tell stories about their families. These stories were primarily visual and oral (recorded) stories. The larger scope was to disrupt normative representations of families while also seeing how children responded to and told stories about family photos.

I was struck by the difficulty of keeping research and consent in the forefront. My experience resonated with Warin's (2011) experience in her 10 -year project with children, specifically how she constantly had to renegotiate consent, especially as her presence became more and more normalized. She built strong relationships with her participants and so she frequently asked them if they wished to continue and what they wished to share. As a researcher, this can be a risky move because data that researchers see as insightful or important may have to be excluded. Earlier, I discussed how relationships can complicate consent, in the research with Stephanie and Kyle, and I brought that understanding to this project. 
Building on the insights from the previous study discussed and drawing on a solid base of research that experimented with a range of participatory methods, in this research the sessions focused much more explicitly on what it means to be a researcher, a research participant, and how participants' stories and ideas are used and shared by researchers. Through early workshops we introduced the idea of children as researchers - already researching their everyday lives and also researchers in this study - and then had each researcher and the teacher share their own family photos.

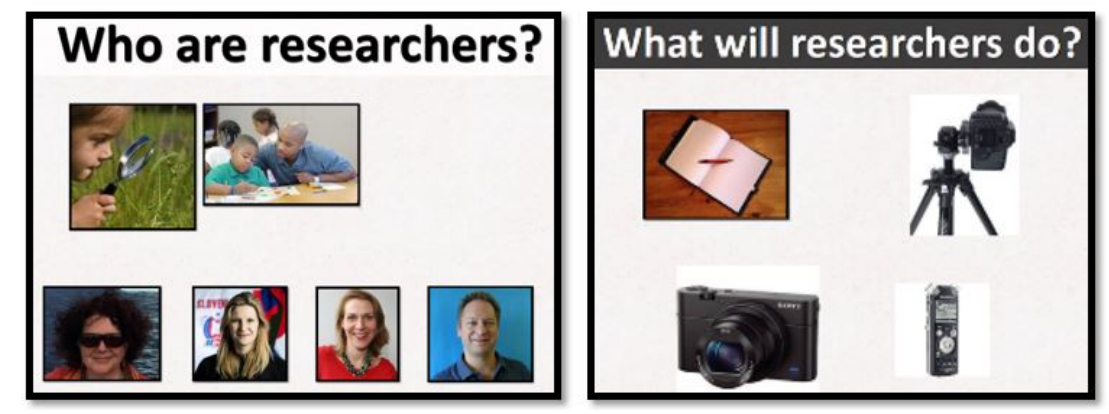

Figure 3. Screenshots of training sessions - children learned about research and being researchers.

In Figure 3 above, there are two screenshots of some of the images and ideas that were shared with children in the research training sessions. On several occasions children also decided to turn off audio recorders during conversations, stating that what they were saying was private. Other children asked not to be video-recorded, some deleted photos, and some just acted very uncomfortable about their photos but also agreed to share them. Several of the children who did not wish to be videotaped reiterated this whenever the camera was near them. Some children expressed discomfort with their own images and expressed this during our debriefs. At the same time, and for the most part, children were willing to share and participate, and they appeared to enjoy the activities and materials. The introduction of the iPad, as a potentially connected device, made them more aware of possible audiences beyond me even though none of them had their own phones or Facebook accounts. They posed for selfies and frequently reviewed, shared and showed their images to their peers, as they are doing in Figure 4. Sometimes they choose to playfully obscure photos, as in this example of a classmate's face covered with a moon face. In this project, parents often chose photos for their children, but all the children had the option to further edit out or delete any photos that they did not want to include in the inquiry. One child/family asked for photos to be blurred. All of the children in the image above assented to having their photos included in the research and in representations that would be shared in presentations and published papers. 
Each child had an iPad assigned to them for the duration of the study, where their photos were stored and that they could delete or keep. One might ask, however, how well children or their families understood how their photos would be shared. In an earlier draft of this paper, I distorted some of the photos from this study. Upon reflecting on this decision, and responding to some reviewer feedback, I decided to honour the consent of the parents and assent of the children. At the same time, I still have some niggling discomfort about potentially vulnerable participants and the intensive scrutiny that research ethics boards give to projects that propose to use images of children. I think that niggling discomfort is a good thing - and something to hold onto while making careful decisions about the ethics of research.

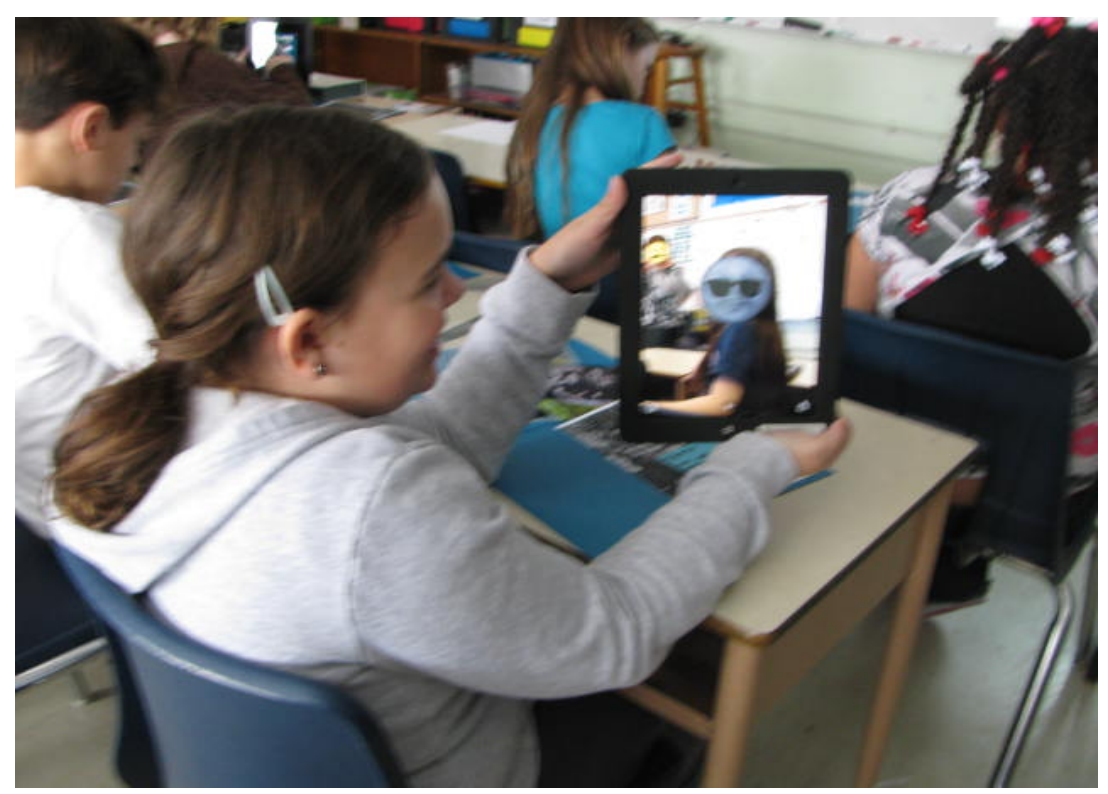

Figure 4. Girl showing picture of friend with emoji head.

In Figure 5 below, the class was working on their photo inquiries and the snapshot gives you a sense of the energy in the room. As mentioned above, most of the children and parents agreed to have original family photos shown in publications as well as any of the children's work and photos of them working. Like the previous photo, I had originally distorted this image. Again, I have made the decision to include it in its original form, while ensuring that everyone pictured agreed to have their image shared. In a recent publication about children's participation and voice in research that featured Kindergarten (five year-old) children, Rogers, Labadie, and Pole (2016) argue that pixelating an image of participants changes the tone and feeling of the data and analysis represented, and does a disservice to the participants 
involved. It is important to note that in this representation and in the paper, it is the researcher who is making these difficult decisions about representation; these are the kinds of decisions that could be made in a more fulsome way with participants.

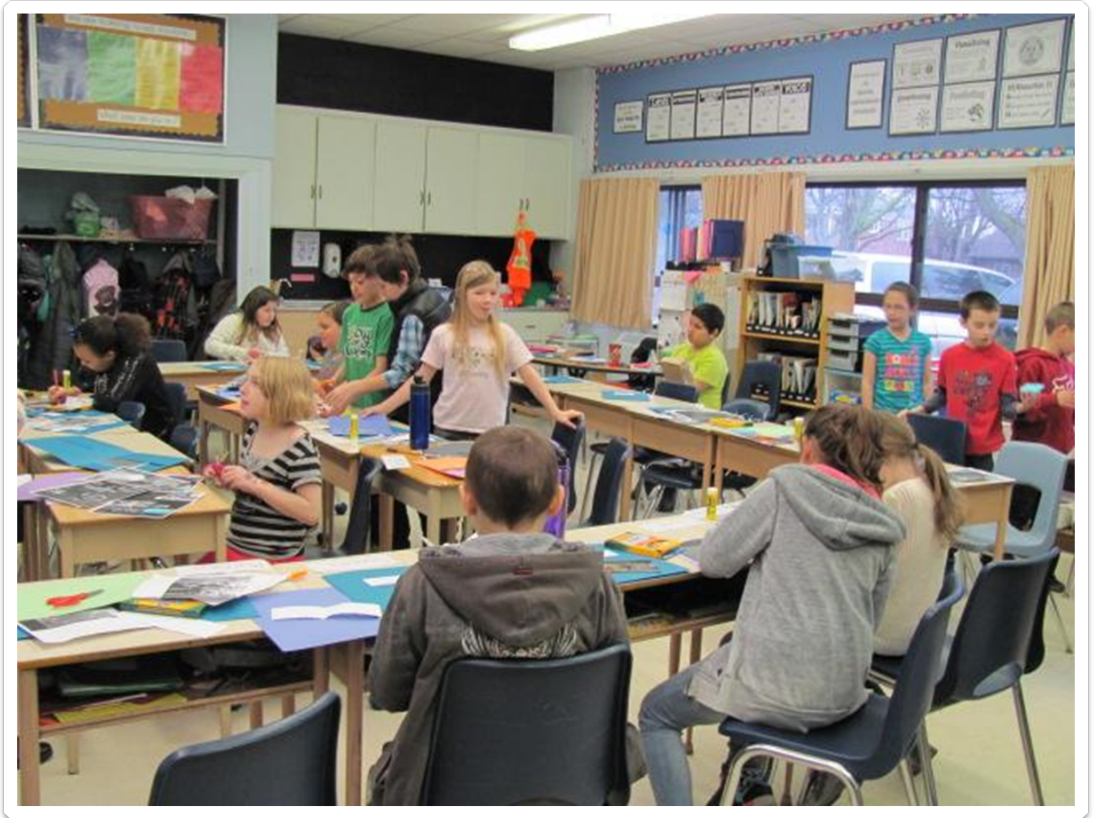

Figure 5. Class making family stories.

In the study I mentioned in the previous section, with Stephanie and Kyle, negotiating ongoing consent was tricky, primarily because they did not see the need for it. My attempts at ongoing negotiation of consent were met with incredulity on the part of Kyle and lack of interest on the part of Stephanie. Kyle would say that I did not need to keep asking about consent as he was so used to what I was doing. This was old hat to him. As research participants, I argue that children are not so different from adults or anyone who might consent to be part of a study. This might seem to contradict the arguments of those who are interested in co-research with children in the hope of presenting children's voices. Beyond the legal and formal ethical distinctions of consent and assent, children seemed to have the same kinds of interest in and indifference to, elements of research studies as would many adult participants. Many adults are willing to participate in research but not as interested in reading transcripts or reviewing artefacts. They might be interested in some elements of research and not in others. Some might participate and not be interested, some might participate and be interested, or this interest might be intermittent. I have found children to be much the same, 
especially in the kinds of research I have presented thus far, where participants have not helped to conceptualize the research process from its beginning.

\section{Co-Researching as Decentring the Researcher}

Finally, co-research can be viewed as an attempt to decentre the researcher within the research, so that participant or co-researcher voices are elevated. This example comes from a recent project, a cross-national study of youth and digital mobilities (DigiYoMo) that took place in Hamilton, Ontario and Glasgow, Scotland. In this project, there was a special interest in social class and digital divides. Over two months, youth met to pose and answer research questions about their digital practices while making art in responses to ideas about digital spaces and online communities. In each site, a group of youth were recruited, in concert with community members. Each group worked with an artist, who worked alongside the lead researcher, research assistants, and collaborators, and youth, to direct the response to ideas and questions about youths' digital practices and spaces (see Figure 6). The artist (a video artist in Hamilton; a sculptor in Glasgow) would do much of the work in the sessions and asked youth to think about social online communities and spaces and respond either by producing material or digital art in responses. The projects ended with community sharing with families, non-profit organization members, and academics.
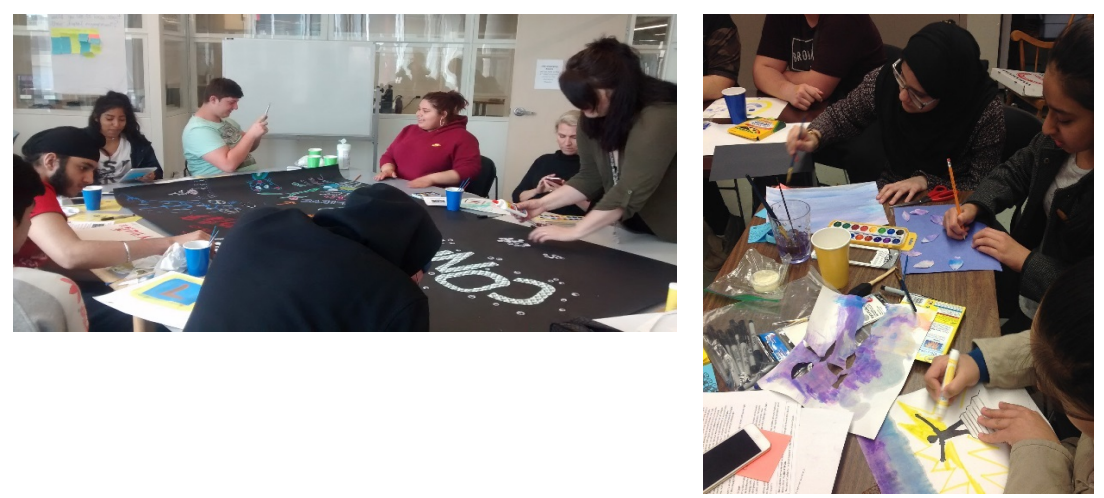

Figure 6: Youth working on representations of digital lives and spaces.

In the two images above, you can see the Hamilton artist working with youth and guiding the inquiry in the Hamilton site. On the left, the artist is leading youth in a group collage where they are meant to represent something from their digital lives. On the right, youth are responding to feeling words about spaces they feel are theirs. In this research, digitized and material 
spaces, practices, and texts bled into each other. Although the intentions were to take a back seat to the artists' and youths' interests, as academic researchers we often found ourselves wondering if our initial research agenda (about mobilities and digital literacy practices and spaces) was being addressed. Because this was a funded project, the Glasgow researcher and I had already spent months talking and writing about the intent and significance of the project. More and more Canadian researchers operate in this way, conceiving research designs in order to fund projects. As part of this process, one gets invested in the ideas to be addressed and the questions to be answered. We got funding to hire the artists, as part of our investment in compensating professionals outside of academia, but as a by-product the researchers were likely more invested in and aware of compelling issues around youth digital mobilities because of the time spent and reading done in advance.

As the project unfolded, conventional research methods and interventions such as interviews and thematizing took place as I intermittently felt compelled to gather the reigns back from the unfolding activities. This is not to say that the project was ill-founded or even unethical, but that there were limits to other people's investment and limits to the researchers' willingness to always see what might happen, especially in a short-term (two month) study where time seemed precious. The youth still developed their own ideas and often contributed complex understandings - they also developed research skills, and these skills and experiences allowed youth to become more involved in directing their own activities and insights. These abilities to direct what happened also changed their perspectives in ways that their initial interests did not usually dictate. In some ways, we naively thought that youth, and the artist, would come with a predetermined set of interests, but the enactment of the arts sessions actually seemed necessary for us all to move to a place of examination and insight. Youth and others developed interests and insights throughout the experiences together. Research is always an intervention, even the kind of research that attempts to control variables and environments. The people, objects, and places are never the same as when events began to unfold (Massey, 2005). This last insight about intervention returns us to the first thread of the paper, following youths' interests.

The two images in Figure 7 illustrate one group's attempts to thematize their personal spaces and their embodied representations of a kind of coding. Like the intentions of the family photo study, here there was a goal of engaging youth in research, the posing of questions, and in analysis. There was a constant toggling back and forth in attempt to forefront the artist's role and push the researcher agenda to the side.

Occasionally, we saw youth trying to please us with predictable responses about online safety and catfishing, but these sometimes contradicted the researchers' sense of their actual digital engagement. Some of the young women insisted that digital tools and practices were diversions from their education and even left the making space on one occasion to interview library 
visitors about their beliefs on education. There were lots of complicated moving pieces, as well as two groups in two countries trying to coordinate their efforts. It was difficult for the academic researchers to move away from traditional qualitative methods to see what might emerge in this arts-informed space. Disruption to usual roles happened, but it was sometimes uncomfortable and disconcerting.
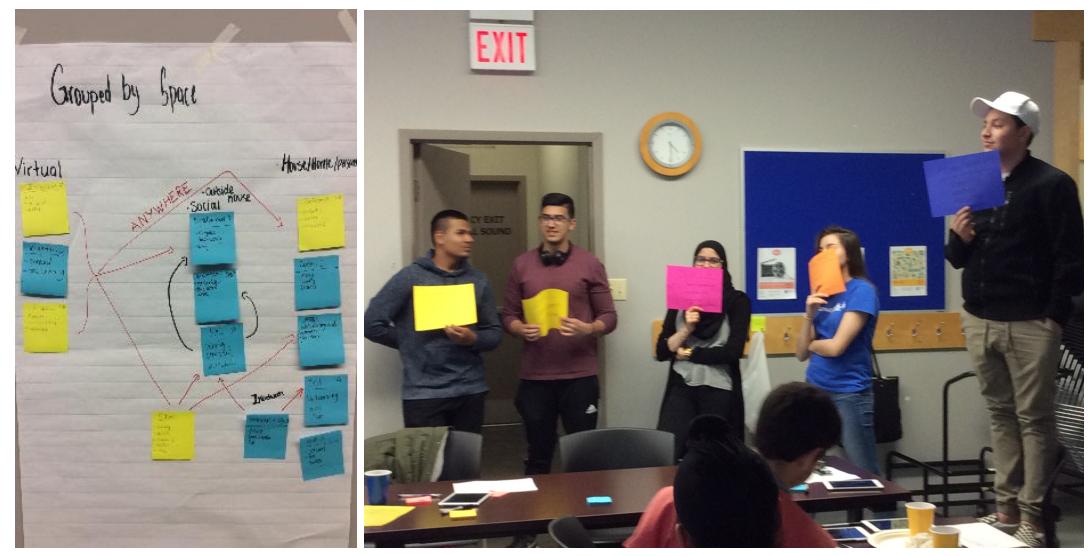

Figure 7. Group product - mapping spaces; making themes in space.

\section{Questions about Co-Research}

At this point, I return to the larger questions posed at the beginning that this examination begins to address: What is co-research? Why co-research? What are the possibilities for and limitations of thinking of young people as coresearchers?

One very appealing thought is to create a continuum of co-research that could allow one to map the degree of involvement of research participants/co-researchers in a research project. I find this prospect very satisfying. In some ways, it solves the problem of the flattening of coresearch claims and allows for nuance, differentiation, and acceptance of different goals for different projects in different contexts, with different people. Horizontally "timing of involvement" could correspond to different phases of research implementation, and vertically "degree of involvement," could refer to the extent to which participants are involved, from minimal to extensive.

You could imagine infinite variations in the ways that research roles might be shared along these axes. Of course, this model breaks down as soon as you start to use it. There are assumptions of linear (versus recursive, or rhizomatic) unfolding of research methods, and then how does one rank degree of involvement? Is more involvement better? While continuing to 
pursue equitable ways of doing research it is equally important to be wary of co-research as the most important, authentic or useful way of doing things.

\section{Co-Research and Ethical Practice}

What might an ethical research practice look like, with others who are unable (legally) to consent to research? For young participants, parents have to complete legal consent forms. Researchers can also encourage children to deny consent in the moment, during data collection and analysis, at any point. Of course, in actuality, they rarely do. Enacting participatory research is a process, undefinable outside of the individuals (young or not) and contexts and sectors in which research happens.

Attempts to co-research should be emergent, open to changing and shifting to the needs of participants or others who are involved. Ethical research needs to be attentive, particularly to the state of being of everyone involved, but also to actions or events that challenge researcher assumptions and desires. Participatory research should be mutually beneficial - that is, children, educators, families, research assistants, researchers, should all benefit from the experience in some ways, and these benefits may be as subtle as an increased self-awareness or a small celebration of interesting insight. In the research with Stephanie and Kyle, the most beneficial element, from the parents' point of view, was the recognition that their children were of interest, that they received attention and time from the researcher. This judgment of benefit is mine alone, however. It is difficult to say how benefit might be seen in the eyes of the different players in the research process. Benefits such as art sessions, food, and attention seem quite small in contrast to the researcher's benefit, which leads to publication and, possibly, promotion. Perhaps benefit can be viewed as an ethical, reflexive, responsive portrayal of lives and leads to insights and learning by others.

Although never fully achievable, ethical research will involve a constant questioning of power roles and relationship dynamics (i.e., in research, in classrooms) and potentially the claims and representations of those involved (Warin, 2011), sometimes by academic researchers and sometimes by the participants if that possibility is built into the research design, which I argue it often could be. A questioning of power roles and relationships is illustrated throughout this paper. For some, when collaboration and dissemination with non-academic communities is paramount, coproduction from inception to completion may be the route that is most powerful and change-making (Bell \& Pahl, 2018; Hackett, Pahl, \& Pool, 2017).

The need for ongoing reflexivity in process cuts across research done in material or virtual spaces and relates to the roles that children might take up or be invited to take up in research. The unfolding of questions, inquiries, and claims need to be flexible and adaptive, keenly focused on participants' needs and responses, and there needs to be benefits for everyone involved. The 
ways in which power relations play out, especially between adults and children, can shift; the researcher can step aside and play a supportive or peripheral role.

Additional considerations for research on digital, civic life (like the focus of these projects) should include and consider audiences, dissemination, and impact - these are heightened when participating in digital spaces but are important in any work with children. There are inevitable parallels between educational research and pedagogy. Jean Ruddick, a renowned promoter of children's participation in schools, wanted to "persuade teachers to see children differently" (Fielding, 2007, p 328). This "seeing" challenges the static ways that those in education tend to describe children as learners, in simplistic and persistent terms such as "successful" or "struggling." An inevitable challenge in participatory or co-research is connected to "how hard it is to learn from voices we do not want to hear" and "to learn to hear the voices we do not know how to hear" (Cook-Sather, 2007, p. 394). What makes "children's voice" studies interesting is the way that usual notions of adult and child or the relationships between generations might be shifted through the research process, even if temporarily. Educational spaces are coconstructed with all players impacting how events are played out "children's places and voices... are tied up with the attitudes, empowerment and participation of adults" (Mannion, 2007, p. 413). One of the goals of coresearch is to honour the perspectives and contributions of children as research participants; this sharing of voice and space is not easily achieved, but worth continuing to describe and enact.

\section{References}

Balen, R., Blyth, E., Calabretto, H., Fraser, C., Horrocks, C., \& Manby, M. (2006). Involving children in health and social research: 'Human becomings' or 'active beings?' Childhood, 13(1), 29-48.

Bell, D. M., \& Pahl, K. (2018). Co-production: Towards a utopian approach. International Journal of Social Research Methodology, 21(1), 105-117.

Bird, J., Colliver, Y., \& Edwards, S. (2014). The camera is not a methodology: Towards a framework for understanding young children's use of video cameras. Early Child Development \& Care, 184(11), 1741-1756.

Bragg, S. (2007). 'But I listen to children anyway!': Teacher perspectives on pupil voice. Educational Action Research, 15(4), 505-518.

Bragg, S. (2010). Consulting young people: A literature review (2nd ed.). Newcastle, UK: Creativity, Culture \& Education.

Buckingham, D., Bragg, S., \& Kehily, M. J. (2015). Rethinking youth cultures in the age of global media: A perspective from British youth studies. Journal of Childhood \& Adolescence Research, 10(3), 265-277.

Christensen, P. M., \& James, A. (2017). Research with children: Perspectives and practices. New York: Routledge.

Christenson, P. H. (2004). Children's participation in ethnographic research: Issues of power and representation. Children \& Society, 18, 165-176.

Clark, A., Flewitt, R., Hammersley, M., \& Robb, M. (2014). Understanding research with children and young people. Los Angeles, CA: Sage.

Studies in Social Justice, Volume 13, Issue 1, 40-58, 2019 
Collier, D. (2014). "I'm just trying to be tough, okay": Masculine performances of everyday practices. Journal of Early Childhood Literacy, 15(2), 203-226.

Collier, D. R. (2017). Rescripting lives and imagining audiences through online multimodal composition. In R. Zaidi \& J. Rowsell (Eds.), Literacy lives in transcultural times (pp. 136154). New York: Routledge.

Cook-Sather, A. (2007). Resisting the impositional potential of student voice work: Lessons for liberatory educational research from poststructuralist critiques of critical pedagogy. Discourse: Studies in the Cultural Politics of Education, 28(3), 389-403.

Cruddas, L. (2007). Engaged voices: Dialogic interaction and the construction of shared social meanings. Educational Action Research, 15(3), 479-488.

Cutter-Mackenzie, A., \& Rousell, D. (2019). Education for what? Shaping the field of climate change education with children and young people as co-researchers. Children's Geographies, 17(1), 90-104.

Dahya, N. (2017). Critical perspectives on youth digital media production: "Voice" and representation in educational contexts. Learning, Media \& Technology, 42(1), 100-111.

Davies, B. (2014). Listening to children: Being and becoming. London \& New York: Routledge.

Dyson, A. (2003). The brothers and sisters learn to write. New York: Teachers College Press.

Fielding, M. (2004). Transformative approaches to student voice: Theoretical underpinnings, recalcitrant realities. British Educational Research Journal, 30(2), 295-311.

Fielding, M. (2007). Jean Ruddick (1937-2007) "Caring a new order of experience": Preliminary appreciation of the work of Jean Ruddick in the field of student voice. Educational Action Research, 15(3), 323-336.

Frost, R. (2007). Developing the skills of seven- and eight-year-old researchers: A whole class approach. Educational Action Research, 15(3), 441-458.

Graue, M. E., \& Walsh, D. J. (1998). Studying children in context: Theories, methods, and ethics. Los Angeles, CA: Sage.

Grover, S. (2004). Why won't they listen to us? On giving power and voice to children participating in social research. Childhood, 11(1), 81-93.

Hackett, A., Pahl, K., \& Pool, S. (2017). In amongst the glitter and the squashed blueberries: Crafting a collaborative lens for children's literacy pedagogy in a community setting. Pedagogies, 12(1), 58-73.

Harland, J. (2007). The voice of young people. Educational Journal, 10(4), 20-30.

Harwood, D. (2010). Finding a voice for child participants within doctoral research: Experiences from the field. Australasian Journal of Early Childhood, 35(4), 4-13.

Hicks, D. (2002). Reading lives: Working-class children and literacy learning. New York: Teachers College Press.

Holland, S., Renold, E., Ross, N. J., \& Hillman, A. (2010). Power, agency and participatory agendas: A critical exploration of young people's engagement in participative qualitative research. Childhood: A Global Journal of Child Research, 17(3), 360-375.

Jackson, A. Y., \& Mazzei, L. A. (2009). Voice in qualitative inquiry: Challenging conventional, interpretive, and critical conceptions in qualitative research. London \& New York: Routledge.

James, A. (2007). Giving voice to children's voices: Practices and problems, pitfalls and potentials. American Anthropologist, 109(2), 261-272.

Jans, M. (2004). Children as citizens: Towards a contemporary notion of child participation. Childhood, 11(1), 27-44.

Leitch, R., Gardner, J., Mitchell, S., Lundy, L., Odena, O., Galanouli, D., \& Clough, P. (2007). Consulting pupils in assessment for learning classrooms: The twists and turns of working with students as co-researchers. Educational Action Research, 15(3), 459-478.

Livingstone, S., \& Sefton-Green, J. (2016). The class: Living and learning in the digital age. New York: New York University Press.

Loutzenheiser, L. W. (2007). Working alterity: The impossibility of ethical research with youth. Educational Studies, 41(2), 109-127.

MacNaughton, G., Smith, K., \& Davis, K. (2007). Researching with children: The challenges and possibilities for building "child friendly" research. In. J. A. Hatch (Ed.), Early childhood qualitative research (pp. 167-184). New York: Taylor \& Francis. 
Madison, D. S. (2011). Critical ethnography: Method, ethics, and performance. Los Angeles, CA: Sage.

Mandell, N. (1988). The least-adult role in studying children. Journal of Contemporary Ethnography, 16(4), 433-467.

Mannion, G. (2007). Going spatial, going relational. Why "listening to children" and children's participation needs reframing. Discourse: Studies in the Cultural Politics of Education, 28(3), 405-420.

Massey, D. B. (2005). For space. London \& Thousand Oaks, CA: Sage.

Medina, C. L., \& del Rocio Costa, M. (2010). Collaborative voices exploring culturally and socially responsive literacies. Language Arts, 87(4), 263-276.

Morrow, V., \& Richards, M. (1996). The ethics of social research with children: An overview. Children \& Society, 10(2), 90-105.

Murray, J. (2017). Welcome in! How the academy can warrant recognition of young children as researchers. European Early Childhood Education Research Journal, 25(2), 224-242.

Pillow, W. (2003). Confession, catharsis, or cure? Rethinking the uses of reflexivity as methodological power in qualitative research. International Journal of Qualitative Studies in Education, 16(2), 175-196.

Price, R. \& Kerr, M. M. (2017). "I thought it was cool how we were part of research": Youth as co-researchers. The Qualitative Report Conference. Retrieved from https://nsuworks.nova.edu/tqrc/eighth/dayl/19/

Punch, S. (2002). Research with children: The same or different from research with adults. Childhood, 9(3), 321-341.

Ravet, J. (2007). Enabling pupil participation in a study of perceptions of disengagement: Methodological matters. British Journal of Special Education, 34(4), 234-242.

Rogers, R., Labadie, M., \& Pole, K. (2016). Balancing voice and protection in literacy studies with young children. Journal of Early Childhood Literacy, 16(1), 34-59.

Semenec, P. (2018). Re-imagining research with children through an engagement with contemporary art. Childhood, 25(1), 63-77.

Snelgrove, S. (2005). Bad, mad, and sad: Developing a methodology of inclusion and a pedagogy for researching students with intellectual disabilities. International Journal of Inclusive Education, 9(3), 313-329.

St. Pierre, E. A. (2011). Post qualitative research: The critique and the coming after. In N. K. Denzin \& Y. Lincoln (Eds.), The SAGE handbook of qualitative research (4th ed.) (pp. 611-625). London: Sage.

Theobald, M. (2012). Video-stimulated accounts: Young children accounting for interactional matters in front of peers. Journal of Early Childhood Research, 10(1), 32-50.

Thomson, R., Berriman, L., \& Bragg, S. (2018). Researching everyday childhoods: Time, technology and documentation in a digital age. London: Bloomsbury Academic.

Tilleczek, K., \& Loebach, J. (2015). Research goes to the cinema: The veracity of videography "with", "for" and "by" youth. Research in Comparative and International Education, 10(3), 354-366.

Warham, K. (2012). Engaging with young people through narrative co-construction: Beyond categorisation. Educational \& Child Psychology, 29(2), 77-86.

Warin, J. (2011). Ethical mindfulness and reflexivity: Managing a research relationship with children and young people in a 14-Year Qualitative Longitudinal Research (QLR) Study. Qualitative Inquiry, 17(9), 805-814.

Studies in Social Justice, Volume 13, Issue 1, 40-58, 2019 